\title{
Antifungal Potential of Chaetomium Species against Fusarium oxysporum f. sp. lycopersici
}

\section{S. Karthika ${ }^{1}$, K. Kalpana ${ }^{1 *}$, S. Harish ${ }^{1}$, M. Theradimani ${ }^{1}$, S. Thiruvudainambi ${ }^{1}$ and $N$. Seenivasan ${ }^{2}$}

\author{
${ }^{1}$ Department of Plant Pathology, Agricultural College and Research Institute, Tamil Nadu \\ Agricultural University, Madurai, Tamil Nadu, India \\ ${ }^{2}$ Department of Nematology, Agricultural College and Research Institute, \\ Tamil Nadu Agricultural University, Coimbatore, Tamil Nadu, India
}

*Corresponding author

\section{A B S T R A C T}

\section{Keywords}

Tomato,

Chaetomium spp.

(Ch. globosum,

Ch. elatum,

Ch. cochiloides,

Ch. bostrychodes),

Fusarium

oxysporum f.sp.

lycopersici and dual

culture technique

etc.,

\section{Article Info}

Accepted:

04 November 2020

Available Online:

10 December 2020
Tomato (Lycopersicon esculentum Mill.) is the most popular vegetable grown across the world. Wilt disease caused by the fungus Fusarium oxysporum f.sp. lycopersici is one of the most devastating and destructive disease of tomato, resulting in significant yield loss. The pathogen causing wilt disease in tomato was isolated and confirmed its pathogenicity in glasshouse experiment. The effect of fungal biocontrol agent Chaetomium spp. was studied against fusarium wilt pathogen under in vitro condition. Among the Chaetomium spp., Ch. cochiloides showed highest inhibition percentage of 64.44 per cent over untreated control against Fusarium oxysporum f.sp. lycopersici.

\section{Introduction}

Tomato (Lycopersicon esculentum Mill.) is one of the most widely cultivated, popular and important vegetable crops in the world. It is used as a fresh vegetable and can be processed and canned as a paste, juice, sauce, powder or as a whole (Barone and Frusciante, 2007). Recently, it started gaining more medicinal value because of the antioxidant property of ascorbic acid and lycopene content (Anonymous, 2002). In India, vegetable cultivation reaches 10.3 million hectares with a production of 175 million 
tonnes, in which tomato is being cultivated in about 808.5 hectares and the production is 19696.9 metric tonnes (MT) with a productivity of $24.4 \mathrm{MT} /$ ha (National Horticulture Board, 2017). In Tamil Nadu, the area under tomato cultivation is 38.78 hectares with production of $840.21 \mathrm{MT} / \mathrm{ha}$ (National Horticulture Board, 2017). The major tomato growing districts in Tamil Nadu are Dharmapuri (which ranks first in area and production), Krishnagiri, Salem, Theni, Dindigul and Coimbatore (Anonymous, 2009). The main constraints in tomato cultivation are pest and diseases and nematode attack. Among the diseases, bacterial wilt (Ralstonia solanacearum), early blight (Alternaria solani), late blight (Phytophthora infestans), fusarium wilt (Fusarium oxysporum f.sp. lycopersici) are the most important one which accounts for maximum yield loss globally. Fusarium wilt is caused $F$. oxysporum f.sp. lycopersici (Sacc.) Snyder and Hansen is a soil borne pathogen and highly specific to tomato and is worldwide in distribution (Walker, 1969). Symptoms associated with $F$. oxysporum f.sp. lycopersici includes yellowing and drooping of the lower leaves. Successive leaves become yellow, wilt and die, often before the plant reaches maturity. Discoloration of the vascular system is characteristic symptom of the disease. Often, infected plants mature earlier and severe infection can lead to a 100 per cent yield loss (Agrios, 2005). It causes significant losses in tomato production both in greenhouse and field-grown tomatoes(Nusret Ozbay and Newman, 2004). It is one of the most prevalent and damaging disease wherever tomatoes are grown intensively because the pathogen can persist indefinitely in the infested soils (Agrios, 1997). Management of soil-borne diseases such as wilt caused by Fusarium sp. has always been problematic. Applying chemical fungicides was considered to be the most effective for plant disease management. The excessive misuse of a wide range of fungicides has led to it being harmful to the environment and increases the resistant pathogenic population (Ozgonen et al., 2001). To overcome this, an alternative method to control the disease had been studied with emphasis on biological control using fungi or bacteria to reduce fungicide application and decrease cost of production. Recently, there have been many reports to control the disease using biological fungicides (Soytong, 1992). Akrami et al., (2011) found that three isolates of Trichoderma harzianum, T. asperellum, $T$. virens were effective against Fusarium rot of lentil. Srinon et al., (2006) reported that $T$. harzianum WS01 showed efficacies of more than $90 \%$ to inhibit conidial production of $F$. oxysporum f.sp. lycopersici and $F$. oxysporum f.sp. cucumerinum (wilt of cucumber). Keeping all these in view, the main objective of this study was to isolate the pathogenic fungus causing fusarium wilt of tomato from various locations of Tamil Nadu and to evaluate the antifungal potential of fungal biocontrol agent namely Chaetomium globosum, Ch. elatum, Ch. cochiloides and Ch. bostrychodes against the isolated pathogen under in vitro condition.

\section{Materials and Methods}

\section{Survey}

A survey was conducted in major tomato growing districts of south Tamil Nadu viz., Madurai, Dindigul, Theni and Coimbatore. Randomly 100 plants were selected in a field and number of plants wilted was counted and the disease incidence was expressed in percentage. The per cent disease incidence was calculated by using the following formula,

Percent disease incidence $(\%)=\frac{\text { Number of plants wilted }}{\text { Total number of plants observed }} \times 100$ 


\section{Isolation of pathogen}

The disease infected samples collected during survey was used for isolation of fusarium wilt pathogen. The wilt infected samples of tomato were collected from different locations of Tamil Nadu during survey. The pathogen was isolated from diseased plants by transferring surface sterilized root tissues onto potato dextrose agar (PDA) medium by using the method of Agrios (1997). Then, single spore isolation was carried out on each isolate to get pure culture and maintained on PDA slants for further studies.

\section{Pathogenicity test}

All Fusarium oxysporum isolates were tested for its pathogenicity in tomato seedlings using Koch's postulates to confirm pathogenic isolates. Briefly, all isolates were sub-cultured and multiplied on PDA medium and incubated at room temperature approximately $30-32^{\circ} \mathrm{C}$ for 7 to 10 days. Then spore suspension was prepared and pathogenic inoculum was adjusted to $1 \times 10^{7}$ spores $/ \mathrm{ml}$ before inoculating to 20 days old tomato seedlings. The roots of tomato seedlings were washed under running sterilized water and cut at five points on the root tips before dipping the roots into a $20 \mathrm{ml}$ spore suspension for 15 mins. A control was maintained by dipping seedlings into sterile water. Then, the seedlings were planted in sterilized soil. After 10 days, symptoms of disease development were recorded using the Disease Severity Index (DSI) and rated according to Sibounnavong et al., (2009) as follows: $1=$ no symptoms, $2=1$ to $20 \%$ of leaves yellow and wilted, $3=21$ to $40 \%$ of leaves yellow and wilted, $4=41$ to $60 \%$ of leaves yellow and wilted, $5=61$ to $80 \%$ of leaves yellow and wilted, $6=81$ to $100 \%$ of leaves yellow and wilted. The experiment was conducted using a completely randomized block design (CRD) with three replications of each treatment and the experiment was repeated two times.

\section{Biocontrol}

The antagonistic fungi viz., Chaetomium globosum 5157, Ch. elatum 3322 were obtained from the Indian Type Culture Collection (ITCC) and Ch. cochiloides 1019, Ch. bostrychodes 2144 were obtained from the Microbial Type Culture Collection (MTCC). These fungal antagonists were sub cultured onto potato dextrose agar (PDA) medium and incubated at $25^{\circ} \mathrm{C}$ in an incubator. Then these isolates were tested against Fusarium sp. under in vitro condition.

\section{In vitro evaluation of fungal antagonists against Fusarium sp.}

The antagonistic fungi were tested against Fusarium oxysporum by using the dual culture technique. The antagonistic fungi tested were Ch. globosum 5157, Ch. elatum 3322, Ch. cochiloides 1019, Ch. bostrychodes 2144. These isolates were tested to influence their ability to antagonize all the Fusarium oxysporum isolates. The test was conducted using the methods of Soytong (1992), Sibounnavong et al., (2009) and Charoenporn et al., (2010). The antagonistic fungi and pathogen were cultured separately on PDA medium at room temperature $30-32^{\circ} \mathrm{C}$ for 7 days. Then, a sterilized cork borer $(0.5 \mathrm{~cm}$ diameter) was used to remove agar plugs from the actively growing edge of cultures of the pathogenic fungus and from antagonistic fungi and then, inoculated onto the PDA plates in such a way that an agar plug of the pathogen was placed on one side of the plate and opposite side an agar plug of an antagonistic fungus was inoculated. The plates inoculated with single plug of the pathogen or antagonist acted as control. Then, these plates were incubated at room temperature $30-32{ }^{\circ} \mathrm{C}$ for 30 days. The 
experiment was carried out in a completely randomized block design (CRD) with three replications. The data were recorded based on colony diameter $(\mathrm{cm})$ and number of conidia produced by the pathogen. A haemocytometer was used to count the number of conidia. The colony diameter or conidia of pathogen were measured and percent inhibition was calculated using the following formula,

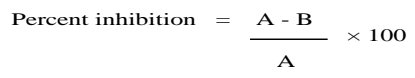

Where, $\mathrm{A}$ is the colony diameter or conidial number of pathogen in control plate and $\mathrm{B}$ is the colony diameter or conidial number of pathogen in dual plate.

\section{Statistical analysis}

All experiments were conducted in a completely randomized block design. Analysis of variance (ANOVA) and the SPSS (Statistical Package for the Social Sciences, version 17.0) were used to analyze the experimental data. The treatment means were compared using DMRT at $\mathrm{P}=0.05$ (Gomez and Gomez, 1976).

\section{Results and Discussion}

\section{Survey}

A survey was carried out in four districts of Tamil Nadu. The results betrayed that wilt disease incidence was noticed in all the districts surveyed viz., Coimbatore, Madurai, Dindigul and Theni districts with a range of 32.00 to 51.33 per cent. Maximum wilt incidence was perceived in Checkkanurani village (51.33 per cent) of Madurai district (Fig. 1) and least incidence was observed in Cumbum (32.00 per cent) of Theni district. The data on per cent wilt disease incidence has been presented in the Table 1. Similar observation was reported by Anitha and Rabeeth (2009) on fusarial wilt of tomato at
Coimbatore and Dindigul districts.

\section{Isolation of disease causing agent}

Ten isolates of Fusarium sp. have been isolated from the infected root portion of the plants collected from various tomato growing areas of Tamil Nadu during survey (Fig. 2). The isolates of Fusarium sp. were named as IS(SEV)-1, IS(THO)-2, IS(AYY)-3, IS(SIN)4, IS(CHE)-5, IS(ACR)-6, IS(USI)-7, IS(MEL)-8, IS(CUM)-9 and IS(SEE)-10 (Table 1). Likewise, Abdel-Salam et al., (2007) justified that the pathogen responsible for wilt ( $F$. oxysporum f.sp. lycopersici) of tomato was isolated from infected roots showing typical symptoms of wilt.

\section{Assessing the virulence of the pathogenic} isolates of Fusarium sp.

Isolates of $F$. oxysporum f.sp. lycopersici [IS(SEV)-1, IS(THO)-2, IS(AYY)-3, IS(SIN)-4, IS(CHE)-5, IS(ACR)-6, IS(USI)-7, IS(MEL)-8, IS(CUM)-9, IS(SEE)-10] were grouped for pathogenicity according to disease severity index (DSI) as shown in the table 2. The wilt disease severity in the pathogen inoculated tomato plants were ranged from 11.11 to 66.67 per cent. Among the ten isolates tested, the Fusarium isolate IS(CHE)-5 collected from Checkkanurani of Madurai district expressed typical symptoms such as yellowing of leaves, wilting of plants, vascular discolouration on inoculated plant after 40 days and showed maximum disease severity of 66.67 per cent wilt incidence followed by 55.56 per cent incidence in the isolate IS(AYY)-3. The remaining isolates of Fusarium sp. recorded 44.44 to 11.11 per cent wilt incidence (Table 2). The pathogenicity test performed on tomato seedlings in this study showed that IS(CHE)-5 was the aggressive isolate. Similar work was reported by Charoenporn et al., (2010). 
Table.1 Survey on the incidence of Fusarium wilt disease incidence in major tomato growing areas of Tamil Nadu

\begin{tabular}{|c|c|c|c|c|c|}
\hline S.No. & Districts & Places & Isolate No. & $\begin{array}{c}\text { Latitude \& } \\
\text { Longitude }\end{array}$ & $\begin{array}{l}\text { Wilt incidence } \\
(\%)\end{array}$ \\
\hline 1 & \multirow[t]{2}{*}{ Coimbatore } & Sevur & IS (SEV)-1 & $\begin{array}{l}11^{0} 16^{\prime} 35.3^{\prime \prime} \mathrm{N} \\
77^{0} 12^{\prime} 34.9^{\prime \prime} \mathrm{E}\end{array}$ & 46.67 \\
\hline 2 & & Thondamuthur & IS (THO)-2 & $\begin{array}{l}11^{0} 16^{\prime} 35.3^{\prime \prime} \mathrm{N} \\
77^{0} 12^{\prime} 34.9^{\prime \prime} \mathrm{E}\end{array}$ & 36.33 \\
\hline 3 & Dindigul & Ayyalur & IS (AYY)-3 & $\begin{array}{l}10^{0} 28^{\prime} 53.9^{\prime \prime} \mathrm{N} \\
77^{0} 42^{\prime} 26.0^{\prime \prime} \mathrm{E}\end{array}$ & 41.33 \\
\hline 4 & \multirow{5}{*}{ Madurai } & Singampunarani & IS (SIN)-4 & $\begin{array}{c}10^{0} 11^{\prime} 50.244^{\prime \prime} \mathrm{N} \\
78^{0} 20^{\prime} 24.75^{\prime \prime} \mathrm{E}\end{array}$ & 35.67 \\
\hline 5 & & Checkkanurani & IS (CHE)-5 & $\begin{array}{c}9^{0} 58^{\prime} 28.7^{\prime \prime} \mathrm{N} \\
77^{0} 56^{\prime} 53.4^{\prime \prime} \mathrm{E}\end{array}$ & 51.33 \\
\hline 6 & & $A C \& R I$ & IS (ACR)-6 & $\begin{array}{c}9^{0} 58^{\prime} 22.1 ” \mathrm{~N} \\
78^{0} 12^{\prime} 14.4^{\prime \prime} \mathrm{E}\end{array}$ & 39.67 \\
\hline 7 & & Usilampatti & IS (USI)-7 & $\begin{array}{c}9^{0} 96^{\prime} 51.1^{\prime \prime N} \\
77^{0} 78^{\prime} 85.3 ” \mathrm{E}\end{array}$ & 32.33 \\
\hline 8 & & Melur & IS (MEL)-8 & $\begin{array}{l}10^{0} 03 ' 33.1 ” \mathrm{~N} \\
78^{0} 33^{\prime} 59.4^{\prime \prime} \mathrm{E}\end{array}$ & 42.67 \\
\hline 9 & \multirow[t]{2}{*}{ Theni } & Cumbum & IS (CUM)-9 & $\begin{array}{c}9^{0} 44^{\prime} 43.7^{\prime \prime} \mathrm{N} \\
77^{0} 15^{\prime} 49.6^{\prime \prime} \mathrm{E}\end{array}$ & 32.00 \\
\hline 10 & & Seelayampatti & IS (SEE)-10 & $\begin{array}{c}9^{0} 58^{\prime} 28.7^{\prime \prime} \mathrm{N} \\
77^{0} 56^{\prime} 53.4^{\prime \prime} \mathrm{E}\end{array}$ & 46.00 \\
\hline
\end{tabular}

Table.2 Pathogenicity of different isolates of Fusarium sp. in tomato

\begin{tabular}{|c|c|c|}
\hline S.No. & Isolate No. & Disease severity $(\%)$ \\
\hline $\mathbf{1}$ & IS (SEV)-1 & 11.11 \\
\hline $\mathbf{2}$ & IS (THO)-2 & 33.33 \\
\hline $\mathbf{3}$ & IS (AYY)-3 & 55.56 \\
\hline $\mathbf{4}$ & IS (SIN)-4 & 22.22 \\
\hline $\mathbf{5}$ & IS (CHE)-5 & 66.67 \\
\hline $\mathbf{6}$ & IS (ACR)-6 & 44.44 \\
\hline $\mathbf{7}$ & IS (USI)-7 & 22.22 \\
\hline $\mathbf{8}$ & IS (MEL)-8 & 44.44 \\
\hline $\mathbf{9}$ & IS (CUM)-9 & 22.22 \\
\hline $\mathbf{1 0}$ & IS (SEE)-10 & 33.33 \\
\hline $\mathbf{1 1}$ & Control & 0.00 \\
\hline
\end{tabular}


Table.3 In vitro efficacy of Chaetomium globosum against the mycelial growth of different isolates of Fusarium sp.

\begin{tabular}{|c|c|c|c|}
\hline S.No. & $\begin{array}{c}\text { Isolates of } \\
\text { Fusarium } \mathbf{p} \boldsymbol{p} .\end{array}$ & $\begin{array}{c}\text { Mycelial growth of Fusarium sp. } \\
\text { against } \text { Ch. } \text { globosum in(cm)* }\end{array}$ & $\begin{array}{c}\text { Mycelial growth inhibition } \\
\text { over control (\%) }\end{array}$ \\
\hline $\mathbf{1}$ & IS (SEV)-1 & $5.2^{\mathrm{c}}$ & $42.22(40.52)^{* *}$ \\
\hline $\mathbf{2}$ & IS (THO)-2 & $5.4^{\mathrm{c}}$ & $40.00(39.23)^{* *}$ \\
\hline $\mathbf{3}$ & IS (AYY)-3 & $5.3^{\mathrm{c}}$ & $41.11(39.88)^{* *}$ \\
\hline $\mathbf{4}$ & IS (SIN)-4 & $4.6^{\mathrm{b}}$ & $48.88(44.36)^{* *}$ \\
\hline $\mathbf{5}$ & IS (CHE)-5 & $4.5^{\mathrm{a}}$ & $50.00(45.00)^{* *}$ \\
\hline $\mathbf{6}$ & IS (ACR)-6 & $6.4^{\mathrm{d}}$ & $28.88(32.51)^{* *}$ \\
\hline $\mathbf{7}$ & IS (US)-7 & $4.2^{\mathrm{a}}$ & $53.33(46.91)^{* *}$ \\
\hline $\mathbf{8}$ & IS (MEL)-8 & $5.3^{\mathrm{c}}$ & $41.11(39.88)^{* *}$ \\
\hline $\mathbf{9}$ & IS (CUM)-9 & $5.5^{\mathrm{c}}$ & $38.88(38.57)^{* *}$ \\
\hline $\mathbf{1 0}$ & IS (SEE)-10 & $6.2^{\mathrm{d}}$ & $31.11(33.90)^{* *}$ \\
\hline $\mathbf{1 1}$ & Control & 9.0 & - \\
\hline CD (P= 0.05) & $\mathbf{0 . 3 2}$ & \\
\hline
\end{tabular}

*Mean of three replications

Mean followed by a common letter are not significantly different at 5\% level by DMRT

**Data in parantheses are arc sine transformed values

Table.4 In vitro efficacy of Chaetomium elatum against the mycelial growth of different isolates of Fusarium sp.

\begin{tabular}{|c|c|c|c|}
\hline S.No. & $\begin{array}{c}\text { Isolates of } \\
\text { Fusarium } \mathbf{~ s p . ~}\end{array}$ & $\begin{array}{c}\text { Mycelial growth of Fusarium sp. } \\
\text { against Chaetomium elatum in } \\
(\mathbf{c m})^{*}\end{array}$ & $\begin{array}{c}\text { Mycelial growth inhibition } \\
\text { over control (\%) }\end{array}$ \\
\hline $\mathbf{1}$ & $\mathrm{FI}_{1}$ & $5.3^{\mathrm{bc}}$ & $41.11(39.88)^{* *}$ \\
\hline $\mathbf{2}$ & $\mathrm{FI}_{2}$ & $6.2^{\mathrm{d}}$ & $31.11(33.90)^{* *}$ \\
\hline $\mathbf{3}$ & $\mathrm{FI}_{3}$ & $7.1^{\mathrm{e}}$ & $21.11(27.35)^{* *}$ \\
\hline $\mathbf{4}$ & $\mathrm{FI}_{4}$ & $6.3^{\mathrm{d}}$ & $30.00(33.21)^{* *}$ \\
\hline $\mathbf{5}$ & $\mathrm{FI}_{5}$ & $5.3^{\mathrm{bc}}$ & $41.11(39.88)^{* *}$ \\
\hline $\mathbf{6}$ & $\mathrm{FI}_{6}$ & $4.2^{\mathrm{a}}$ & $53.33(46.91)^{* *}$ \\
\hline $\mathbf{7}$ & $\mathrm{FI}_{7}$ & $6.4^{\mathrm{d}}$ & $28.88(32.51)^{* *}$ \\
\hline $\mathbf{8}$ & $\mathrm{FI}_{8}$ & $5.1^{\mathrm{b}}$ & $43.33(41.17)^{* *}$ \\
\hline $\mathbf{9}$ & $\mathrm{FI}_{9}$ & $7.2^{\mathrm{e}}$ & $20.00(26.57)^{* *}$ \\
\hline $\mathbf{1 0}$ & $\mathrm{FI}_{10}$ & $5.6^{\mathrm{c}}$ & $37.77(37.92)^{* *}$ \\
\hline $\mathbf{1 1}$ & $\mathrm{Control}$ & 9.0 & \\
\hline $\mathbf{C D}(\mathbf{P}=\mathbf{0 . 0 5})$ & $\mathbf{0 . 3 5}$ & \\
\hline
\end{tabular}

*Mean of three replications

Mean followed by a common letter are not significantly different at $5 \%$ level by DMRT

**Data in parentheses are arc sine transformed values 
Table.5 In vitro efficacy of Chaetomium cochiloides against the mycelial growth of different isolates of Fusarium sp.

\begin{tabular}{|c|c|c|c|}
\hline S.No. & $\begin{array}{c}\text { Isolates of } \\
\text { Fusarium } \\
\text { sp. }\end{array}$ & $\begin{array}{c}\text { Mycelial growth of Fusarium sp. against } \\
\text { Chaetomium cochiloides in }(\mathbf{c m})^{*}\end{array}$ & $\begin{array}{c}\text { Mycelial growth inhibition } \\
\text { over control (\%) }\end{array}$ \\
\hline $\mathbf{1}$ & $\mathrm{FI}_{1}$ & $5.1^{\mathrm{c}}$ & $43.33(41.17)^{* *}$ \\
\hline $\mathbf{2}$ & $\mathrm{FI}_{2}$ & $4.3^{\mathrm{b}}$ & $52.22(46.27)^{* *}$ \\
\hline $\mathbf{3}$ & $\mathrm{FI}_{3}$ & $3.3^{\mathrm{a}}$ & $63.33(52.73)^{* *}$ \\
\hline $\mathbf{4}$ & $\mathrm{FI}_{4}$ & $4 .^{\mathrm{b}}$ & $53.33(46.91)^{* *}$ \\
\hline $\mathbf{5}$ & $\mathrm{FI}_{5}$ & $5.6^{\mathrm{d}}$ & $37.77(37.92)^{* *}$ \\
\hline $\mathbf{6}$ & $\mathrm{FI}_{6}$ & $3.3^{\mathrm{a}}$ & $63.33(52.73)^{* *}$ \\
\hline $\mathbf{7}$ & $\mathrm{FI}_{7}$ & $3.2^{\mathrm{a}}$ & $64.44(53.39)^{* *}$ \\
\hline $\mathbf{8}$ & $\mathrm{FI}_{8}$ & $5.3^{\mathrm{cd}}$ & $41.11(39.88)^{* *}$ \\
\hline $\mathbf{9}$ & $\mathrm{FI}_{9}$ & $4.4^{\mathrm{b}}$ & $51.11(45.64)^{* *}$ \\
\hline $\mathbf{1 0}$ & $\mathrm{FI}_{10}$ & $5.4^{\text {cd }}$ & $40.00(39.23)^{* *}$ \\
\hline $\mathbf{1 1}$ & $\mathrm{Control}$ & 9.0 & \\
\hline $\mathbf{C D}(\mathbf{p}=\mathbf{0 . 0 5}$ & $\mathbf{0 . 3 1}$ & \\
\hline
\end{tabular}

*Mean of three replications

Mean followed by a common letter are not significantly different at $5 \%$ level by DMRT

**Data in parentheses are arc sine transformed values

Table.6 In vitro efficacy of Chaetomium bostrychodes against the mycelial growth of different isolates of Fusarium sp.

\begin{tabular}{|c|c|c|c|}
\hline S.No. & $\begin{array}{c}\text { Isolates of } \\
\text { Fusarium sp. }\end{array}$ & $\begin{array}{c}\text { Mycelial growth of Fusarium sp. } \\
\text { against Chaetomium bostrychodes in } \\
\text { (cm)* }\end{array}$ & $\begin{array}{c}\text { Mycelial growth inhibition } \\
\text { over control (\%) }\end{array}$ \\
\hline $\mathbf{1}$ & $\mathrm{FI}_{1}$ & $6.3^{\mathrm{d}}$ & $30.00(33.21)^{* *}$ \\
\hline $\mathbf{2}$ & $\mathrm{FI}_{2}$ & $6.2^{\mathrm{d}}$ & $31.11(33.90)^{* *}$ \\
\hline $\mathbf{3}$ & $\mathrm{FI}_{3}$ & $6.2^{\mathrm{d}}$ & $31.11(33.90)^{* *}$ \\
\hline $\mathbf{4}$ & $\mathrm{FI}_{4}$ & $6.6^{\mathrm{e}}$ & $26.66(31.08)^{* *}$ \\
\hline $\mathbf{5}$ & $\mathrm{FI}_{5}$ & $5.7^{\mathrm{c}}$ & $36.66(37.26)^{* *}$ \\
\hline $\mathbf{6}$ & $\mathrm{FI}_{6}$ & $6.2^{\mathrm{d}}$ & $31.11(33.90)^{* *}$ \\
\hline $\mathbf{7}$ & $\mathrm{FI}_{7}$ & $5.3^{\mathrm{b}}$ & $41.11(39.87)^{* *}$ \\
\hline $\mathbf{8}$ & $\mathrm{FI}_{8}$ & $4.5^{\mathrm{a}}$ & $50.00(45.00)^{* *}$ \\
\hline $\mathbf{9}$ & $\mathrm{FI}_{9}$ & $6.4^{\mathrm{de}}$ & $28.88(32.50)^{* *}$ \\
\hline $\mathbf{1 0}$ & $\mathrm{FI}_{10}$ & $5.6^{\mathrm{c}}$ & $37.77(37.92)^{* *}$ \\
\hline $\mathbf{1 1}$ & $\mathrm{Control}_{2}^{\mathbf{C}} \mathbf{C D}(\mathbf{p}=\mathbf{0 . 0 5})$ & 9.0 & \\
\hline
\end{tabular}

*Mean of three replications

Mean followed by a common letter are not significantly different at $5 \%$ level by DMRT

**Data in parentheses are arc sine transformed values 
Fig.1 Symptoms of Fusarium wilt of tomato Fig.2 Mycelial growth of Fusarium oxysporum f.sp. lycopersici
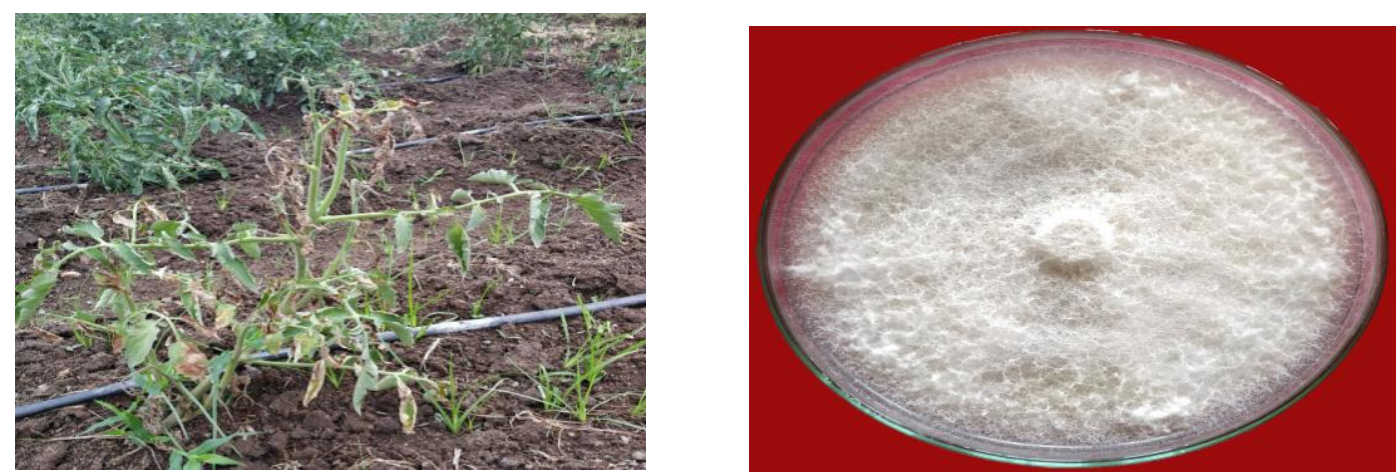

Fig.3 In vitro efficacy of Chaetomium globosum against the mycelial growth of different isolates of Fusarium sp.

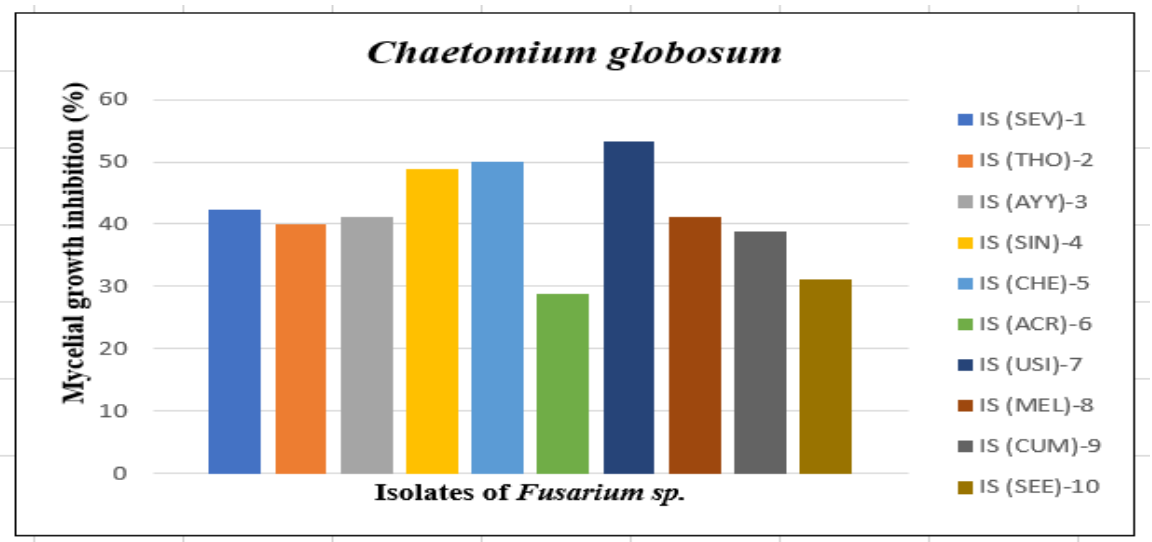

Fig.4 In vitro efficacy of Chaetomium elatum against the mycelial growth of different isolates of Fusarium sp.

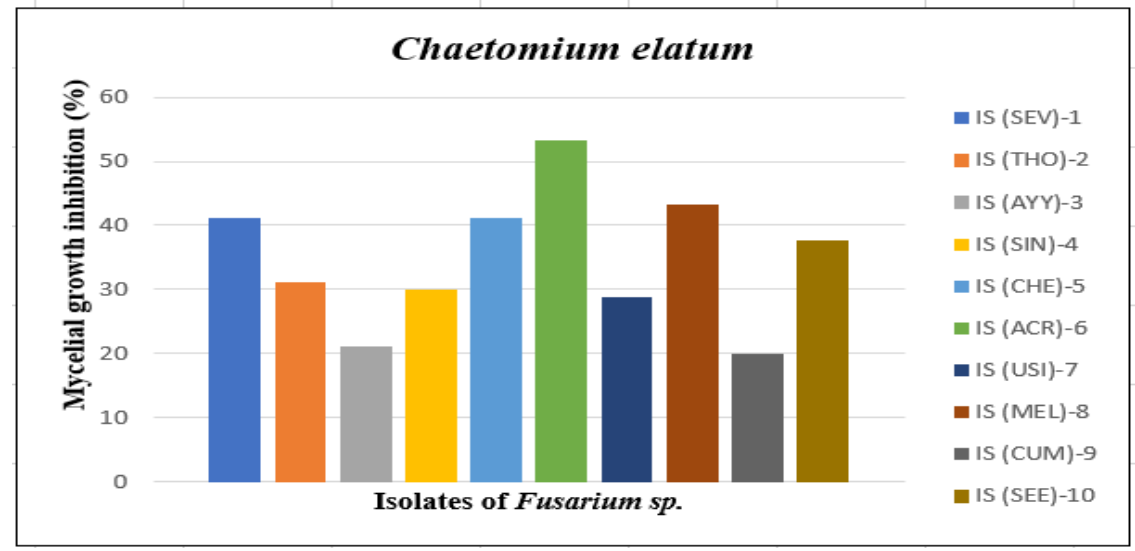


Fig.5 In vitro efficacy of Chaetomium cochiloides against the mycelial growth of different isolates of Fusarium sp.

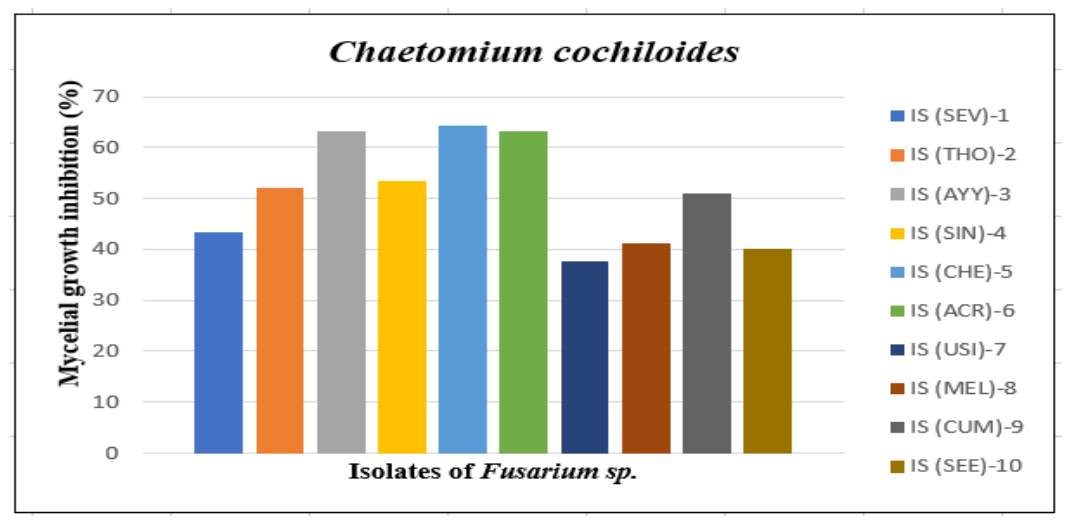

Fig.6 In vitro efficacy of Chaetomium bostrychodes against the mycelial growth of different isolates of Fusarium sp.

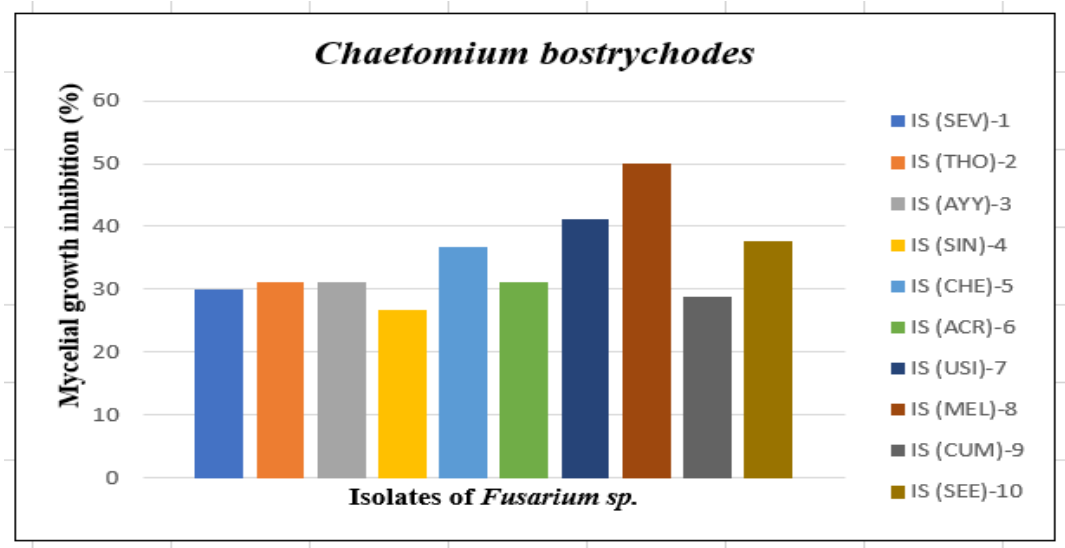

\section{Biocontrol}

The fungal biocontrol agent viz., $C h$. globosum 5157, Ch. elatum 3322, Ch. cochiloides 1019 and Ch. bostrychodes 2144 tested against the ten isolates of $F$. oxysporum f.sp. lycopersici. Similarly, Charoenporn et al., (2010) brought antagonistic fungi $C h$. globosum, N0802, Ch. lucknowense CLT and T. harzianum PC01 from Assoc. Prof. Dr. Kasem Soytong of King Mongkut of the Institute of Technology Ladkrabang, Thailand and tested the efficacy of the antagonists against wilt fungus under in vitro.
In vitro evaluation of fungal antagonists against Fusarium sp.

In vitro antagonism of Ch. globosum against the mycelial growth of ten isolates of Fusarium sp. indicated that, the antagonist was very effective in inhibiting the mycelial growth of isolates of Fusarium sp. [IS(USI)7] to the maximum of 53.33 per cent. This was followed by IS(CHE)-5 with 50.00 per cent, IS(SIN)-4 with 48.88 per cent and IS(SEV)-1 with 42.22 per cent. The least mycelial growth reduction was recorded in the isolate IS(ACR)-6 with 28.88 per cent (Table 3, Fig 3). Correspondingly, Phong et 
al., (2015) showed that the antagonistic fungi namely Ch. cupreum CC3003, Ch. globosum CG05 and Ch. lucknowense CL01 inhibited NHP-Fusa-2 using bi-culture technique. Then, the fungal antagonist $C h$. elatum showed the maximum inhibition percentage to an extent of 53.33 per cent against the mycelial growth of Fusarium sp. isolate IS(ACR)-6. This was followed by the isolate IS(MEL)- 8 which exhibited the mycelial growth reduction of 43.33 per cent over control (Table 4, Fig 4). Similar results were reported by Charoenporn et al., (2010) in tomato against $F$. oxysporum f.sp. lycopersici. The fungal biocontrol agent Ch. cochiloides was most effective against the isolate of Fusarium sp. IS (CHE)-5 to the maximum inhibition percentage of 64.44 per cent (Table 5, Fig 5). The fungal antagonist Ch. bostrychodes exhibited the maximum inhibition against the isolate of Fusarium sp. IS(MEL)-8 to an extent of 50.00 per cent followed by the isolate IS(USI)-7 with growth reduction of 41.11 per cent (Table 6, Fig 6). The results showed that among the four species of the antagonist tested, $C h$. cochiloides showed more inhibition percentage of 64.44 per cent against $F$. oysporum f.sp. lycopersici followed by $C h$. globosum, Ch. elatum and Ch. bostrychodes. Sibounnavong et al., (2011) studied that $C h$. elatum significantly inhibited mycelial growth of $F$. oxysporum f.sp. lycopersici to 74.95 per cent followed by Ch. lucknowense and Emericella rugulosa. Phong et al., (2015) reported that Ch. cupreum CC3003, Ch. globum CG05 and Ch. lucknowense CL01 significantly inhibited both mycelial growth and conidial production of $F$. oxysporum NHP-Fusa-2 to the range from 31.69 to 34.03 per cent. The least inhibition was noticed against the isolate IS(USI)-7 (Table 5, Fig 5).

In conclusion this study showed that $C h$. cochiloides exhibited more inhibition percentage of 64.44 per cent against $F$. oxysporum f.sp. lycopersici followed by $C h$. globosum, Ch. elatum and Ch. bostrychodes. These biocontrol agents are better alternative for managing the most devastating disease of fusarium wilt in tomato. The testing of these isolates against the wilt pathogen in tomato is under pipeline.

\section{Acknowledgement}

The authors would like to express sincerely thanks to the Dean, Agricultural College and Research Institute, Madurai for providing necessary facilities to conduct the study. We also thank the Indian Type Culture Collection (ITCC) and Microbial Type Culture Collection (MTCC) for providing a cultures.

\section{References}

Abdel-Salam, M., M. Abd El-Halim, and O. El-Hamshary. 2007. Improvement of Pseudomonas antagonism against Fusarium oxysporum through Protoplast fusion: I-Fusants induction. Research Journal of Cell and Molecular Biology 1:37-41.

Agrios, G.N. 1997. Plant Pathology, The 4th edition, Academic Press, San Diego.

Agrios, G.N. 2005. Plant Pathology, The 5th Edition, Academic Press, San Diego.

Akrami, M., H. Golzary, and M. Ahmadzadeh. 2011. Evaluation of different combinations of Trichoderma species for controlling Fusarium rot of lentil. African Journal of Biotechnology 10:26532658.

Anitha, A., and M. Rabeeth. 2009. Control of Fusarium wilt of tomato by bioformulation of Streptomyces griseus in green house condition. Afr. J. Basic. Appl. Sci. 1:9-14.

Anonymous. 2002. Asian Vegetable Research Development, Taiwan, Annual Report, pp.110.

Anonymous. 2009. Science Reporter. In vitro 
and in silica studies on bio control agent of bacterial strains against Fusarium oxysporum f.sp. lycopersici. Research in biotechnology., 3:22-31.

Barone, A., and L. Frusciante. 2007. Molecular marker-assisted selection for resistance to pathogens in tomato. Food and Agriculture Organization of the United Nations (FAO): FAO.

Charoenporn, C., S. Kanokmedhakul, F. Lin, S. Poeaim, and K. Soytong. 2010. Evaluation of bio-agent formulations to control Fusarium wilt of tomato. Afr. J. Biotech., 9:5836-5844.

Gomez, K.A., and A.A. Gomez. 1976. Statistical procedure for agriculture research 2nd edn: John Wiley and Sons, New York, USA.

National Horticulture Board. 2017.

Nusret Ozbay, and Newman. 2004. Fusarium crown and root rot of tomato and control methods. Plant Pathol. J., 3:9-18.

Ozgonen, H., M. Bicici, and A.O. Erkilic. 2001. The effect of salicyclic acid and endomycorrhizal fungus Glomus etunicatumon plant development of tomatoes and Fusarium wilt caused by Fusarium oxysporum f.sp lycopersici. Turk. J. Agric. For. 25: 25-29.

Phong, N.H., W. Pongnak, and K. Soytong. 2015. Antifungal activities of
Chaetomium spp. against Fusarium wilt of tea. Plant Protection Science 52:10-17.

Sibounnavong, P., C. Charoenporn, S. Kanokmedhakul, and K. Soytong. 2011. Antifungal metabolites from antagonistic fungi used to control tomato wilt fungus Fusarium oxysporum f. sp. lycopersici. Afr. J. Biotechnol., 10:19714-19722.

Sibounnavong, P., K. Soytong, and N. Ecija. 2009. In vitro biological activities of Emericella nidulans, a new fungal antagonist, against Fusarium oxysporum f. sp. lycopersici. J. Agric. Technol., 5:75-84.

Soytong, K. 1992. Biological control of tomato wilt caused by Fusarium oxysporum f. sp. lycopersici using Chaetomium cupreum. Kasetsart J.(Nat. Sci.) 26:310-313.

Srinon, W., K. Chuncheen, K. Jirattiwarutkul, and K. Soytong. 2006. Efficacies of antagonistic fungi against Fusarium wilt disease of cucumber and tomato and the assay of its enzyme activity. J. Agric. Technol. 2:191-201.

Walker, J.C. 1969. Plant Pathology, McGraw-Hill Book Co., New York, pp.819.

\section{How to cite this article:}

Karthika, S., K. Kalpana, S. Harish, M. Theradimani, S. Thiruvudainambi and Seenivasan, N. 2020. Antifungal Potential of Chaetomium Species against Fusarium oxysporum f.sp. lycopersici. Int.J.Curr.Microbiol.App.Sci. 9(12): 189-199. doi: https://doi.org/10.20546/ijcmas.2020.912.026 